\title{
Uso y función de la estampa suelta en los Siglos de Oro (Testimonios literarios)
}

En una sociedad como la española de los siglos XVI y XVII, en la que el 80 por 100 de sus miembros no practicaban la lectura ', forzosamente los medios de difusión de la cultura habían de ser mayoritariamente orales y plásticos. Entre estos últimos destacan, por su alcance social, los que formaban parte de la decoración de lugares accesibles a la contemplación indiscriminada del público, y las estampas sueltas. Éstas eran piezas de coste comparativamente muy bajo, que cumplían sobre todo una función devocional y que en ocasiones, en especial en los estratos de bajo poder adquisitivo, sustituían a las pinturas. Su carácter de objetos con los que convivían cotidianamente todos los grupos sociales hace que más de una vez la literatura (en su sentido más amplio) se haya interesado por ellos.

Se pueden diferenciar dos grandes tipos de vínculos entre grabado y literatura. Por una parte los que existen entre las estampas y el soporte que mayoritariamente acogía a la obra literaria: el libro impreso, que frecuentemente alojaba también a aquéllas ${ }^{2}$. Por otra, los que se establecen cuando la estampa, o algunos usos relacionados con ella, pasa a ser objeto de reflexión literaria. En estas páginas queremos recoger algunos ejemplos de este segundo tipo de relación, que esperamos sirvan para acercarnos a algunos aspectos relacionados con el consumo y la función de las estampas, a los que no es fácil acceder mediante otras fuentes.

El tipo de estampa suelta al que se refieren la mayor parte de los testimonios escritos es la devocional, aunque no faltan alusiones a aquellas que cumplen una función informativa o a las que reproducen pinturas?

1 Maxime ChevalieR, Lectura y lectores en la España del siglo XVI y XVII (Madrid: Turner, 1976).

2 Véase sobre todo Juan CARrete Parrondo, «El grabado y la estampa barroca», en Juan CARrete, Fernando CHECA y Valeriano Bozal, El grabado en España (Ss. XVI-XVIII) (Madrid: Espasa-Calpe, 1987), 247-282. También Blanca GARCÍA VEGA, El grabado del libro español (Valladolid, Institución Cultural Simancas, 2 vols., 1984). Una aproximación perspicaz a una de las dimensiones del tema se encuentra en José María Dfez Borque, «Aspectos de la recepción y difusión de la novela de caballerías castellana del siglo Xvi: sobre edición e ilustraciones», Spigilegio Moderno, 15-16 (1981), 39-64.

3 J. CARRETE, «Notas sobre la estampa como medio de comunicación», en el catálogo de la exposición Técnicas tradicionales de estampación (Madrid, Museo Municipal, 1980), 23-34. 


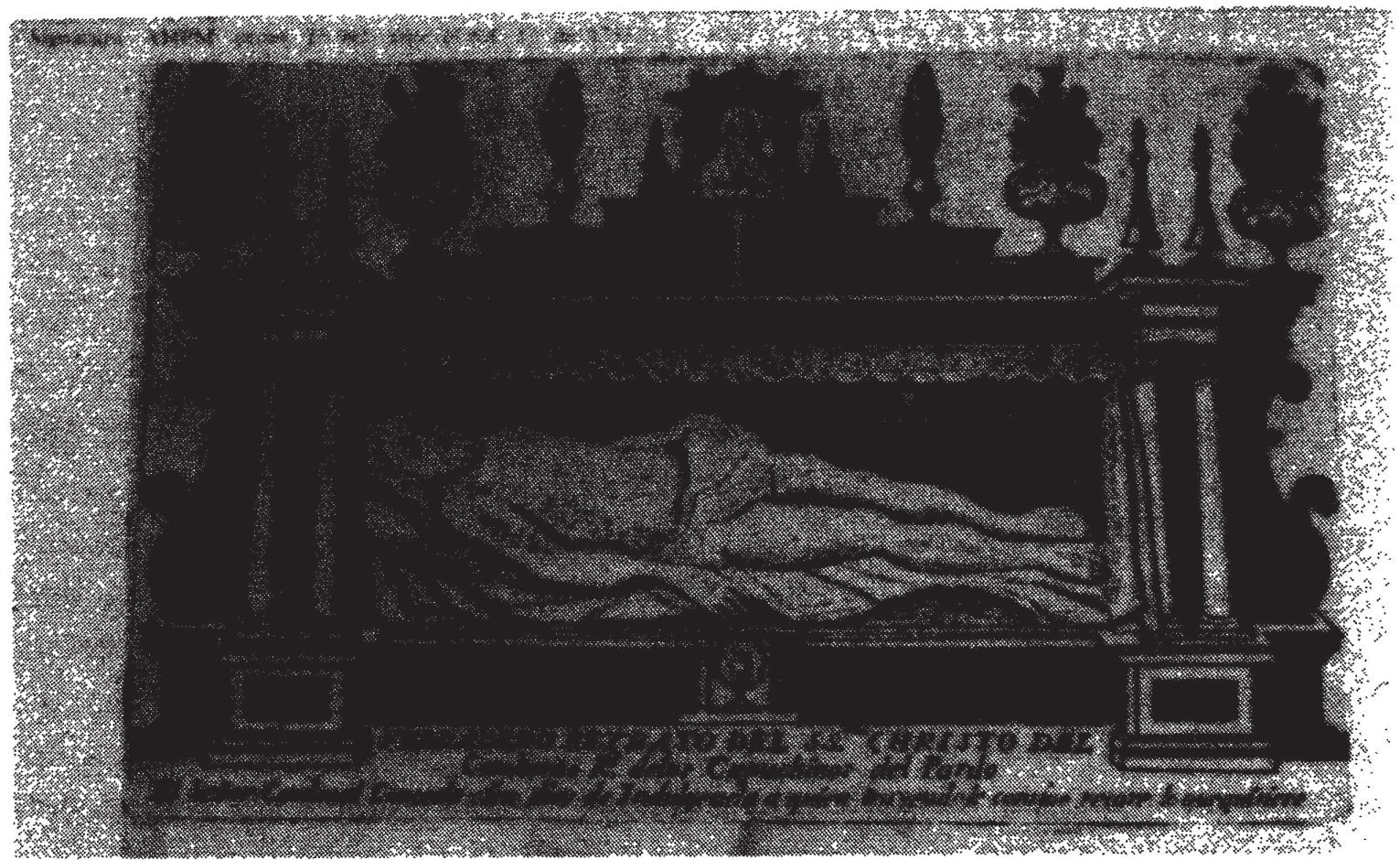

Fic. 1. Santo Cristo del Pardo. Anónimo del siglo Xvill.

A pesar de que, a causa de la fragilidad del medio y de la poca estima que merecían, apenas han llegado hasta nuestros días piezas de este tipo, su producción debió de ser muy numerosa, y su procedencia preferentemente extranjera, en el caso de las que representan advocaciones comunes a todo el mundo católico, y española cuando se trataba de devociones de carácter local. Parece ser que no es posible apreciar diferencias sustanciales entre los temas más frecuentados por este tipo de obras y los habituales en otros medios de expresión artística. Pero si buena parte de las pinturas y esculturas pueden ser consideradas objetos destinados a la devoción colectiva, en el caso de las estampas tenemos que hablar de un uso íntimo y una función protectora personal ${ }^{4}$. Frecuentemente hacían las veces de medallas y se colocaban en el pecho. Esto hizo el estimable arquitecto Miguel de Soria, autor de las iglesias madrileñas del Carmen y las Carboneras, según nos cuenta en su diario:

4 Las estampas de San Antonio Abad, p.e., protegían del fuego, como nos cuenta Ceballos en sus Flores del yermo (1685): "Valiéndose sus devotos con estampas y retratos, puestos a vista del fuego, milagrosamente quedar atajado, y no pasar adelante con su voracidad». Citamos por Julio Caro BAROJA, Las formas complejas de la vida religiosa (Madrid: Akal, 1978), 98. Los aspectos devocionales del grabado han sido últimamente tratados en María del Carmen MONTORO CABRERA, «El grabado como plasmación de la religiosidad popular», La religiosidad popular. II: Vida y muerte. La imaginación religiosa, comp. Carlos Álvarez Santaló (Barcelona: Anthropos, 1989), 190-201. Especial interés ha tenido la exposición Arte y devoción. Estampas de imágenes y retablos de los siglos XVII y XVIII en las iglesias madrileñas (Madrid: Calcografía Nacional, 1990), cuyo catálogo incluye textos de Antonio Bonet y Juan Carrete. 
Y fue Dios servido y la Virgen Stma, usar con migo un milagro q yendo a una fiesta de la Virgen del Oyo que está en la Sierra q se apareció en una ençina me trajeron una estanpita de papel y me la puse en el coraçón y encomendándome a la Soberana Señora la prometí un vestido y dos achas, lo qual fue ella servida de q se hiçieses.

Al tema aluden también los pliegos de cordel, lo que les servía a los ciegos para hacer propaganda de uno de los géneros que, como veremos, fue objeto de su comercio. En La desgraciada Ginesa, el padre de la protagonista saca de su pecho un «retrato» de la Virgen de Montserrat y una hoja con los «santos Evangelios» (Probablemente similar a la que lleva prendida de la cintura el protagonista del Capricho n. 4 de Goya, El de la Rollona. Ver lám. III) y, después de venerarlos, su hija sana. Se trata de una pieza muy interesante para el estudio de las fuentes gráficas de inspiración de la literatura popular, pues la imagen de Ginesa con dos culebras agarradas a sus pechos está directamente inspirada en las representaciones de la Lujuria que tanto abundan en la escultura románica ${ }^{6}$. A la estampa de la Virgen del Carmen que llevaba en su pecho se encomienda «Don Eusebio de Herrera» tras el naufragio que sufrió después de haber asesinado a una mujer y al hijo de ambos. La Virgen le salva y resucita a sus víctimas. Enterado el obispo, «... manda / que de este raro portento / caracteres se fijaran / en las puertas de los templos / para que el cristiano traiga / consigo aqueste retrato / para su defensa y guarda. / Concedió cuarenta días / de indulgencia a todas cuantas / devotas personas pongan / en su pecho aquesta estampa / de la soberana Madre, / del Carmen Reina sagrada» '. Probablemente el pliego de cordel, que sólo conocemos por la transcripción de Durán, aparecía encabezado por una imagen de la Virgen del Carmen.

De lo difundida que estaba la costumbre de llevar en el pecho estampas que representaban imágenes religiosas tenemos pruebas en las relaciones de milagros atribuidos a éstas, como los que narra Ares en su libro sobre la madrileña Virgen de la Soledad, donde, por ejemplo, nos cuenta que a un peón de albañil apenas le ocurrió nada al caer de un alto andamio, debido a que tenía en su pecho una imagen "de las bastas de papel» ${ }^{8}$. También Lope de Vega se hace eco del carácter esencialmente mueble y personal de las estampas, y así en $E l$ mayorazgo dudoso nos narra cómo una que repre-

5 Miguel de Soria, Noticias de Madrid (Biblioteca Nacional de Madrid, Mss. 9856), fol. $18 \mathrm{r}$.

6 Agustín DURÁN (Ed.), Romancero general (Madrid: Atlas, 1945), II, 350-351.

A. Durán, Op. cit., II, 348-350.

8 Antonio ARES, Discurso del ilustre origen y grandes excelencias de la misteriosa Imagen de Nuestra Señora de la Soledad... (Madrid: Pedro Taco, 1640). En José Simón DIAZ, Fuentes para la bistoria de Madrid y su provincia (Madrid: I.E.M., 1964), I, 303 y 305. 
senta a la Virgen con el Niño pasa de un cautivo cristiano moribundo a otro, quien la utiliza para adoctrinar al protagonista 9 . Unos versos de otra obra dramática de este escritor, el auto Nuestro bien, son muy expresivos de lo asociada que estaba a la estampa religiosa su ubicación junto al corazón. En ellos, San José, jugando con las distintas posibilidades semánticas del verbo «estampar», dice así del Niño Jesús: «Siempre le traigo estampado / en mi pecho, y si pudiera / en el alma le trujera / como un papel retratado» ${ }^{10}$.

En ocasiones las estampas no sólo eran objeto de devoción personal, pues se exhibían públicamente y su influencia se extendía a una colectividad. A ello hace referencia un pasaje de la biografía de Fray Raimundo de Lumbier:

Viniendo a visitarle un día el Reverendíssimo Padre Escuela, Provincial de San Francisco, le encontró con un Corista a quien estava personalmente asistiendo en el exercicio de ir clavando en todas las puertas de su celda, y de las de su Colegio unas Imágenes de papel de el Santíssimo Sacramento, en tiempo que corrió ganava Indulgencia el que saludasse aquel Retrato. Quedó assombrado este Padre de averlo hallado en semejante exercicio, y salió (sobre ser el Oráculo de la eloquencia) ignorando, cómo ponderar tantas luzes de virtud, y exemplo, como en sola aquella acción avía concebido, por ver a un Hombre de tan autorizada suposición reducido a una piedad tan menuda, como aquella ${ }^{11}$.

Al repasar los repertorios bibliográficos de nuestros Siglos de Oro sorprende encontrar gran cantidad de impresos de carácter informativo, en los que se describen sucesos como fiestas, batallas, etc., y que debieron de ser ampliamente consumidos. Pero el peculiar carácter de algunas de estas noticias del interés general hacía que la forma más certera de darlas a conocer no fuera la letra impresa, sino la imagen. A ello se debe precisamente la relativa abundancia de estampas que representan, por ejemplo, fenómenos anormales de la naturaleza o planos de batallas ${ }^{12}$. La literatura se hizo eco de este tipo de obras, que circularon bastante a juzgar por lo

9 Obras de Lope de Vega, Ed. Emilio Cotarelo (Madrid: R.A.E., 1916-1930), VII, 481-482.

10 Obras de Lope de Vega, Ed. Marcelino Meńendez Pelayo (Madrid: Atlas, 19631972), VII, 87a.

11 Joseph Boneta, Vida exemplar del V.P.M. Fr Raymundo de Lumbier (Zaragoza: D. Gascón, 1687), 68.

12 J. Carrete, «Estampas. Cinco siglos de imagen impresa», en el catálogo de la exposición Estampas: cinco siglos de imagen impresa (Madrid: Ministerio de Cultura, 1981), 32 . 
que indican los repertorios epistolares ${ }^{13}$. Lope de Vega se refiere en $E l$ animal de Hungría al retrato impreso de un «monstruo»:

REy.-Días ha que decía / que de este monte, en lo espeso / aqueste animal había.

BARTOLo.-Ya su retrato anda impreso, / y se cantan cada día / las coplas de sus traiciones ${ }^{14}$.

En los preliminares del Orfeo en lengua castellana se alude irónicamente a un retrato de una de estas desviaciones de la naturaleza para atacar al culteranismo: «Q trayendo estos días un pez retratado con rostro humano, y las demás partes compuestas de arcabuzes, flechas, espadas y tiaras, huvo quien dixo, que no se desvelassen en su pronóstico, que era poema culto" ${ }^{15}$.

A pesar de que en España la gente prefería decorar su casa con una mala pintura a hacerlo con buenas estampas (lo que explica una producción de cuadros en ocasiones casi industrializada), abundaban los hogares en los que los únicos objetos que colgaban en las paredes eran éstas. En general esto se debía a una falta de recursos económicos, según muestra la literatura, que utiliza la alusión a la posesión de estampas para definir el bajo nivel económico y social de algún personaje. Mendo, un criado que interviene en la comedia lopesca El desprecio agradecido, describe así su cuarto: «Hay mesa, estampa, candil, / peine, silla, limpiadera, / calzador y todo, en fin / para tu servicio, Sancho» ${ }^{16}$. Una caracterización similar de un interior humilde hace Cervantes en su novela Rinconete y Cortadillo:

Se atrevió Rincón a entrar en una sala baja, de dos pequeñas que en el patio estaban, y vio en ella dos espadas de esgrima y dos broqueles de corcho, pendientes de cuatro clavos, y un arca grande, sin tapa ni cosa que la cubriese, y otras tres esteras de enea tendidas por el suelo. En la pared frontera estaba pegada a la pared una imagen de Nuestra Señora, de estas de mala estampa, y más abajo pendía una esportilla de palma, y, encajada en la pared, una almofía blanca ${ }^{17}$.

Del papel que a veces jugaban las estampas en el ajuar doméstico como sustitutivos de las pinturas es muy expresivo un párrafo que incluye Francisco

13 Jerónimo de Barrionuevo, Avisos, Ed. A. PAZ (Madrid: Atlas, 1968), II, 73a, 74b, 78b. Cartas de algunos padres de la Compañia de Jesús (Madrid: R.A.H., 1861-1865), VI, 472 .

14 Obras de Lope de Vega, Ed. E. Cotarelo (Madrid: R.A.E., 1916-1930), III, 427b.

15 Juan Pérez De MONTAlbán, Orfeo en lengua castellana (Madrid: Viuda de Alonso Martín, 1624), preliminares.

16 Comedias escogidas de Lope de Vega (Madrid: Atlas, 1946-1952), II, 259.

17 Costumbristas españoles, Ed. Evaristo CoRrEa (Madrid: Aguilar, 1964²), I, 11. 
Santos en su Día y noche de Madrid, donde uno de los personajes, después de oir ponderar a otro el «estrado y colgaduras de la cama, adorno de pinturas, escritorios...» de su dama, le tacha de exagerado e indica que «los escritorios serán una arquilla de seis reales ... Las pinturas serán cuatro papelones amalgamados de los que traen los franceses» ${ }^{18}$.

No conocemos con exactitud qué temas se representaban con mayor frecuencia en las estampas que decoraban las paredes de un buen número de las casas humildes españolas, aunque probablemente eran similares a los que se reproducían en las pinturas de consumo doméstico: es decir, aunque no faltarían retratos o series de alegorías como las Partes del Mundo, los Elementos o las Estaciones, predominarían las escenas devocionales. De hecho, de tema religioso son tanto la estampa que cita Cervantes («Nuestra Señora») como la que se representa pegada a la pared en el cuadro atribuido a Puga La mujer sentada (Museo del Prado) ${ }^{19}$ (ver lám. IV).

No siempre la sustitución de pinturas por estampas se debía a escasez de recursos económicos, pues a veces tenía su origen en un deseo expreso de «ostentar» humildad. Así, el adorno de las celdas del monasterio madrileño de la Concepción Francisca se reducía voluntariamente a «unas estampas de papel y esas pocas devotas», lo que debía de contrastar mucho con la riqueza de las celdas de otros conventos madrileños ${ }^{20}$. Por su parte, Fray Raimundo de Lumbier sustituyó los cuadros de su cuarto por imágenes de papel, según nos cuenta Boneta en su biografía:

Aviendo parecido precisso a otros Religiosos de su clase tener adornada la celda con pinturas de objetos píos, y sagrados, quando no por sí, por los que los visitavan; a N.V.P. no se lo pareció; pues teniéndola adornada de muchos quadros, y entrando en su celda con tanta frequencia, todo lo grande y noble de Zaragoza, se deshizo de este adorno, subrogándolo en imágenes de papel, diziendo: que un Religioso hasta las paredes de la Celda avía de tener desnudas ${ }^{21}$.

Este mismo personaje alcanzó cierta fama por la cantidad y suntuosidad de los templos que mandó labrar, lo que no había de extrañar en una época que, en lo que a comportamiento religioso se refiere, admiraba tanto las ma-

18 Ed. M. NAvarro PÉrez (Madrid: I.E.M., 1976), 183-184.

19 Algunos lo han creído un retrato de la madre del pintor. Pero la atribución a Puga, y mucho más la identificación del modelo con su madre, es discutible. Véase Diego ANGULo Í̃̃gueZ y Alfonso Emilio PÉREZ SÁnCHEZ, Pintura madrileña del segundo tercio del siglo XVII (Madrid: I.D.V.), 1982, 268 y 274.

20 Alonso Remón, Relación de la exemplar vida y muerte del Cavallero de Gracia (Madrid: Diego Flamenco, 1620), fol. 60v.

21 BONETA, Op. cit., 32. 
nifestaciones personales de austeridad y humildad como las colectivas de lujo y esplendor.

Al igual que ocurre respecto de los interiores laicos, conservamos una pintura que atestigua la existencia de estampas en las paredes de las celdas de los religiosos. Se trata del San Francisco confortado por un ángel que guarda el Wadsworth Atheneum de Hartford y se atribuye a Ribalta ${ }^{22}$ (ver lám. I). Sobre el lecho del santo, pegada a la pared, aparece una estampa que representa una Crucifixión.

Todos estos testimonios inducen a pensar que una estampa en una pared era ante todo índice de pobreza. Una pobreza a veces buscada y querida, pero más frecuentemente no deseada; en ocasiones sólo aparente, pero casi siempre real. Esto no quiere decir que el grabado fuera un arte menospreciado, pues de hecho lo practicaron artistas de renombre e incluso personalidades como Juan José de Austria. Por otra parte, aunque es difícil encontrar coleccionistas españoles de estampas que no fueran artistas (quienes las utilizaban por razones profesionales), se valoraban mucho los libros que las contenían, y prácticamente toda la población haría alguna vez uso de ellas por razones devocionales. Además, ya había españoles, como Crisóstomo Martínez, perfectamente conscientes de las grandes posibilidades del grabado para difundir nuevas técnicas y conocimientos ${ }^{23}$, que convirtieron a este medio artístico, como demostró Ivins, en uno de los motores que impulsaron la gran revolución técnica que Occidente experimentó en la Edad Moderna ${ }^{24}$.

Como se ha dicho en varias ocasiones, la mayor parte de las estampas sueltas que circularon por España durante los Siglos de Oro procedían del extranjero, fundamentalmente de Flandes, Italia y Francia ${ }^{25}$. Allí nacieron también algunos de los mejores grabadores que trabajaron en nuestro país. La producción española debió de ser relativamente escasa, de carácter fundamentalmente devocional y de poca calidad. De todo ello se lamenta Jusepe Martínez en un párrafo famoso ${ }^{2 \kappa}$. En cuanto a los medios de difusión de este tipo de obras, existieron fundamentalmente dos: la venta y el regalo.

Una interesante carta de un jesuita, fechada en Madrid en 1642, nos informa de que entre los presentes que la Condesa de Olivares acababa de enviar

22 David Kowal, Ribalta y los ribaltescos (Valencia: Diputación Provincial, 1985), 254.

23 Sobre Martínez véase Antonio Gallego, Historia del grabado en España (Madrid: Cátedra, 1979), 205-206, o J. CARRETE, «El grabado y la estampa...», 317-320.

24 William M. Ivins Jr., Imagen impresa y comunicación visual (Barcelona: Gustavo Gili, 1975).

25 J. CARRETE, «El Grabado...», 231.

26 Jusepe Martínez, Discursos practicables del nobilísimo arte de la pintura (c. 1675), Ed. Vicente CARDERERA (Madrid: R.A.B.A.S.F., 1866), 170. 
al Duque de Nochera, por entonces preso y enfermo, figuraba «una estampa y medida, y un botijón de agua de Santo Domingo en Soriano, barros y vidrios de Valencia» ${ }^{27}$, lo que nos confirma la extensión del uso de estampas devocionales a todos los estratos sociales. De la costumbre de regalar este tipo de piezas también se hace eco Lope de Vega, en cuya comedia La vengadora de mujeres Laura quiere recompensar a su alumna Diana, a la que dice: «Hoy quisiera / tener que darte» ${ }^{28}$. A ello responde, para sí, Julio: «Pues déle / una estampa». La intención es claramente irónica, aunque el significado exacto de «dar una estampa» se nos escapa. En todo caso, y teniendo en cuenta lo difundido que estuvo el regalo de este tipo de objetos, parece que en esta frase podemos ver también el reflejo de un uso pedagógico habitual, que se ha conservado hasta casi nuestros días.

Dentro del mundo hispánico, la relación entre grabado y pedagogía fue bastante estrecha en Iberoamérica, donde la población indígena no disponía en sus templos del amplio repertorio de imágenes que en cualquier iglesia peninsular facilitaba al pueblo la asimilación de la historia sagrada y de los dogmas eclesiásticos. Precisamente la voluntad de catequizar llevó a Fray Juan Bautista, un religioso activo en Méjico, a elaborar unos «Hieroglíficos de conversión, donde por estampas y figuras se enseña a los naturales el aborrecimiento del pecado y deseo que deben tener al bien soberano del cielo» ${ }^{29}$. Algo parecido, aunque no referido exclusivamente a América, nos cuenta Juan de Butrón que hacían los jesuitas Juan Baptista Romano y Pedro Canisio, autor este último del Catechismus minor latinus, ilustrado con cincuenta estampas:

Para catechizar a la Iglesia los hijos que quisieren criarse debaxo de sus alas, halló una maravillosa invención el Padre Juan Baptista Romano, y después del el Padre Pedro Canisio, ambos de la Compañía de Jesús, que pusieron todos los rudimentos con que se deven dotrinar los idiotas, y enseñar los niños desde el persignum crucis, hasta la última de las oraciones que la Iglesia tiene, por estampas, que alientan el afecto aprehendiendo lo que allí se les muestra, imitando lo que se les pone pintado ${ }^{30}$.

27 Cartas de algunos padres de la Compañia de Jesús (Madrid: R.A.H., 18611865), VII, 296.

28 Obras escogidas de Lope de Vega, Ed. Federico Carlos SÁlnz de Robles (Madrid: Aguilar, 1966'), I, 1576b.

29 No se conserva esta obra. Habla de ella su autor en su Sermonario. Véase J. Simón Dfaz, Bibliografía de la Literatura Hispánica (Madrid: I.M.C.), XII, n. 3008.

30 Juan de Butrón, Discursos apologéticos en que se defiende la ingenuidad del arte de la pintura (Madrid: Luis Sánchez, 1626), fol. 90v. Sobre el libro de Canisio véase Alfonso Rodríguez G. DE CEBAllos, «Las "Imágenes de la Historia Evangélica" del P. Jerónimo Nadal en el marco del jesuitismo y la Contrarreforma», Traza y Baza, n." 5 (1974), 81-82. 
No sorprende en absoluto que esta iniciativa haya partido de unos miembros de la Compañía de Jesús, una orden que siempre se mostró muy amiga de utilizar los recursos plásticos con fines pedagógicos. Prueba de ello es el impulso que dieron a la literatura emblemática y la promoción que hicieron de libros en los que, como en las Imágenes de la historia Evangélica de Nadal, existía una voluntad manifiesta de integrar texto e imagen (lám. II). Precisamente en la obra de Alciato, el más famoso de los libros de emblemas, aprendió de niño las primeras letras uno de los personajes de la Guía y aviso de forasteros que vienen a la corte, de Pedro Liñán ${ }^{31}$.

Dado el predominio de la imagen devocional en las estampas sueltas que circulaban por España en los Siglos de Oro, no es de extrañar que buena parte de las referencias que poseemos sobre el regalo de este tipo de objetos se relacionen con el clero. Sus miembros no sólo se enviaban unos a otros estas piezas, como atestiguan las cartas de jesuitas ${ }^{32}$, sino que también en ocasiones las distribuían gratuitamente entre la población con objeto de promover ciertas devociones, como la de la Virgen gallega de los Ojos Grandes, en una de cuyas estampas aparece impreso: «Esta insignia se ha de dar graciosa, sin que por ella se dé cosa alguna" ${ }^{33}$. Un ejemplo bastante expresivo de este tipo de acciones aparece en San Nicolás de Tolentino, una comedia de Lope de Vega:

NICOLÁS. — ¿Tienes rosario?

LABRADOR.-Sí, padre.

NiColÁs.-Pues récenle cada día / a la divina María, / pura Virgen, de Dios Madre; / tomen estas estampitas, / y en ellas pueden rezar, / no se olvidando de dar / a Dios gracias infinitas / siempre que les dé sustento ${ }^{34}$.

31 Ed. E. Simons (Madrid: Editora Nacional, 1980), 56.

32 Cartas de algunos padres de la Compañia de Jesús (Madrid: R.A.H., 1861-1865), II, 102, o V, 510.

33 F. CHECA, «La imagen impresa en el Renacimiento y el Manierismo", en J. Carrete, F. Checa y V. Bozal, El grabado en España (Ss. XVI-XVIII) (Madrid: EspasaCalpe, 1987), 158. Se reproduce en el catálogo de la Exposición Estampas: cinco siglos..., Op. cit., n. 84 .

34 Obras escogidas de Lope de Vega, Ed. F. C. SÁINZ DE ROBLES (Madrid: Aguilar, 1966), III, $249 \mathrm{~b}$. 


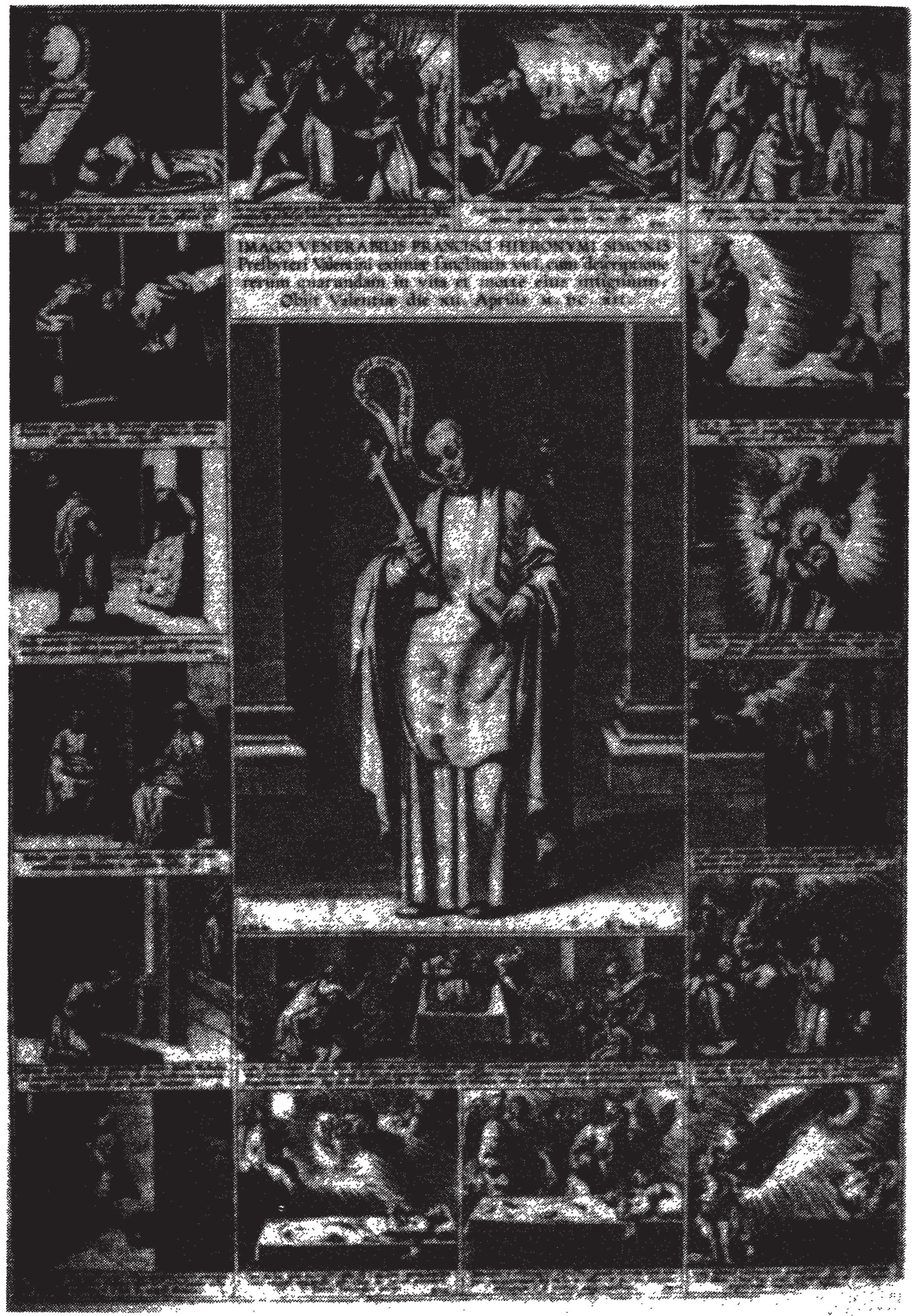

Fici. 2. Escenas de la vida del P. Jerónimo Simó. M. Lasne. Hacia 1615. 
Las fiestas religiosas, muy abundantes en la España barroca, eran acontecimientos que propiciaban de modo extraordinario la impresión y difusión de nuevas estampas. Esto era particularmente cierto cuando celebraban beatificaciones o canonizaciones, pues por medio del grabado se podía difundir la biografía de los nuevos santos y beatos y su nueva iconografía. En Valencia, en 1620, con motivo de las fiestas por la beatificación de Santo Tomás de Villanueva, se veían por las calles:

los niños, ombres i mugeres todos ocupados: unos aziendo faroles ya blancos, i ordinarios, ya de papeles de colores, ya de pintura, ya de estampa de mil maneras, i dibuxos, cosa que xamás se vio en Valencia, con tanta variedad como diremos. Otros por las calles vendiendo a cargas candilejos de barro para dichos faroles. Otros aziendo infinitas arrobas de velas de sevo para lo mismo, que se hazen en esta ciudad por ecelencia. Otros, estampas, i figuras del Santo, de que uvo sin número, pues solo los Religiosos trajeron de Roma, más de tres mil de folio grande finísimas, con sus milagros en contorno de ellas por orla; sin otras muchas, que mercaderes particulares avían echo traer a su cuenta, $i$ infinitas de diferentes suertes, que en la ciudad se avían cortado en madera, $i$ láminas de cobre, de que uvo tan notable expedición, que admira ${ }^{35}$

El otro medio de difusión de la estampa suelta era la venta, que, por lo que deja ver la documentación, se llevaba a cabo en porterías de conventos y santuarios, en librerías y directamente en la calle, por medio de estamperos. Dada la procedencia de la mayor parte de las piezas que circulaban por España, estos tipos de vendedores se abastecían preferentemente de mercaderes extranjeros, y así en 1655 Mateo Guerra y Margarita Daben declaran estar convenidos con

Juan Poule y Enrrique Dupont, mercaderes de lonja, flamencos, residentes en esta Corte, en que ayamos de bender y despachar por su quenta en nuestra casa y tienda cantidad de papeles, estampas y vitelas que para este efecto nos an entregado y obligarnos a que les pagaremos lo que dellas procediere conforme a los precios que emos ajustado $=$ Por tanto otorgamos $[\ldots]$ haber reçivido $[\ldots]$ diferentes estampas y papeles de Rubenes y Vandiche $[\ldots]$ y treçientas piezas de

35 Geronymo MARTf́NeZ DE LA VEGA, Solenes y grandiosas fiestas, que [...] Valencia a echo por la Beatificación de [...] D. Tomás de Villanueva (Valencia: Felipe Mey, 1620), 23-24. Quedan algunas piezas de este tipo, así como otras descripciones literarias. Entre éstas una de Lope de VEGA (que fue el autor de su iconografía) en la Relación de las fiestas [...] de Madrid [...] en la canonización de San Isidro (Madrid, Viuda de Alonso Martín, 1622), preliminares; y otra de Juan Antonio de la PEÑa en su Elogio del S.P.F. de Borja [...] en su gloriosa beatificación (Madrid: Juan Delgado, 1625), fol. 1v. Sobre la de Lope he tratado en «Lope de Vega y el grabado», Goya, n. $205-206$ (1988-1989), 49-51. 
Milagros de Santo Domingo, y treçe mil pieças en otavo y quarto de diferentes Santos y Santas, y otras dos mil de un folio, las mil dellas de Nuestro Señor Jesuchristo y las otras mil restantes de diferentes Santos y Santas $=\mathrm{Y}$ otras dos mil quinientas estampas de vitela de Boutatos $=\mathrm{Y}$ otras çinco mil y doçientas y treinta y dos estampas de vitela de diferentes autores y Santos y Santas $=\mathrm{Y}$ mil y çien librillos del Misterio de la Missa con cubiertas coloradas $=Y$ otras diferentes pieças, estampas y papeles de Rubenes, finas y ordinarias, grandes, chicas y medianas, de Santos y Santas y de paysaje y de aprender a pintar y otras diferentes ${ }^{36}$.

Estas cifras son suficientemente expresivas de la gran difusión que la estampa suelta alcanzó en España durante la Edad Moderna. Otro mercader de estampas que actúa en Madrid en el siglo XVII es Manuel del Campo, que tenía su tienda en la Puerta del Sol y, probablemente, hay que identificar con el «librero de Su Majestad» del mismo nombre ${ }^{37}$.

\section{EL ESTAMPERO}

Los párrafos que siguen, dedicados a analizar la figura del estampero, constituyen una prueba de la importancia que puede llegar a tener la literatura como fuente histórica; pues, aunque no conocemos ni documentación de archivo ni fuentes gráficas de los Siglos de Oro que nos permitan definir las características de este tipo de comerciante, sí poseemos suficientes alusiones literarias como para hacerlo. Buena parte de ellas se localizan en obras teatrales; y si tenemos en cuenta que los usos sociales que reflejaban las comedias y autos sacramentales eran generalmente aquellos con los que estaba muy familiarizado todo el público, podemos decir que la venta callejera de estampas era una costumbre habitual. A los vendedores no siempre se les conocía con el nombre de estamperos y en ocasiones no se dedicaban exclusivamente al comercio de estos objetos. Algo de esto ocurre, por ejemplo, con los «santeros» a los que alude Alonso de Contreras en su autobiografía:

Amaneció y dieron traza para que yo entrase en las dos casas sin escándalo a reconocerlas. $Y$ fue que entrando en otras primero, decían era enviado del obispo de Badajoz, a ver las casas si tenían imágenes y cruces, y como yo era ermitaño, creyéronlo. $\mathrm{Y}$ fue causa que vinieron santeros con estampas de papel a Hornachos

36 Mercedes Agullo, Más noticias sobre pintores madrileños de los siglos XVI al XVIII, (Madrid: Ayuntamiento, 1981), 211.

37 M. Agulló, «Noticias de impresores y libreros madrileños de los siglos xVI y XVII», Anales del Instituto de Estudios Madrileños, I (1966), 177. 
que se hicieron ricos, y no había puerta que no tuviese dos o tres cruces, que parecía campo de matanza ${ }^{38}$.

No sabemos si a la palabra «santeros» hay que darle el significado que le otorgan Covarrubias y el Diccionario de Autoridades, o si en realidad designa a simples estamperos, cuyo objeto principal de comercio era la estampa devocional, a la que, según parece, alguna vez se ha denominado «santo» ${ }^{39}$. En todo caso, el texto parece aludir a la necesidad que tenían los habitantes de ciertas zonas españolas, en las que había habido una importante población musulmana, de albergar imágenes cristianas en sus casas para así probar, o aparentar, su ortodoxia religiosa. Sin embargo, en ocasiones, estas estampas se convertían precisamente en los objetos donde algunos de ellos descargaban su resentimiento, como sugiere Fonseca que hacían los moriscos: «Las Imágenes de los Santos que con particular mandato de los visitadores tenían en sus casas, siempre las víamos mal puestas, unas veces de lado, otras cabeça abajo, llenas de suciedad, de telarañas, y razgadas» ${ }^{40}$.

Las estampas formaban a veces parte del repertorio de objetos que vendían los ciegos, aunque, al contrario de lo que ocurre respecto de los pliegos de cordel, no parece que éstos hayan tenido nunca el monopolio de su comercio ${ }^{41}$. De esta actividad se hace eco Ríos Hevia en su relación de las fiestas vallisoletanas por la beatificación de Santa Teresa. Nos cuenta que a la salida de misa

también se detenían en oyr muchas oraciones de la Santa hechas a diferentes propósitos de sus excelencias, y rezadas por diestros y devotos ciegos [...] Andavan también muchos destos medio ciegos vendiendo cantidad de retratos de la Santa, que no se davan manos a venderlos. En cuya diligencia como era tanta la devoción de todos, ganaron estos con las estampas y retratos, y los otros a rezar muy a gusto de su desseo ${ }^{42}$.

38 Alonso de Contreras, Vida del Capitán Alonso de Contreras (Madrid: Alianza, 1967), 160.

39 A los iluminadores de estampas se les denominaba «pinta-santos». Véase Joan AmADES, «Las estampas», Bibliofilia, IX (1957), 32. Debo el conocimiento de este artículo a la gentileza de Jesusa Vega. A ella y a Juan Carrete les quiero agradecer desde aquí sus sugerencias y ayuda.

40 Damián FonseCA, Justa expulsión de los moriscos de España (Roma: Iacomo Mascardo, 1612), 128.

41 María Cruz Garcia DE ENTERrfa, Sociedad y poesía de cordel en el Barroco (Madrid: Taurus, 1971), 78.

42 Manuel de los Rfos Hevia, Fiestas que hizo la insigne ciudad de Valladolid con Poesías y Sermones en la Beatificación de la Santa Madre Teresa de Jesús (Valladolid: Francisco Abarca de Angulo, 1615), fols. 21v-22r. 
Unos versos, quizá de Juan de Matos, que se incluyen en un cancionero de la Biblioteca Nacional, aluden a la fusión entre literatura oral e imagen gráfica que tan frecuentemente acompañaba a la actividad de los ciegos. Se incluyen en el romance "A Santo Domingo en Soriano», y dicen así:

\section{Mándenme rezar devotos de S. Domingo Soriano, que soy un ciego que cuento la vida de este retrato ${ }^{43}$.}

Su significado es voluntariamente ambiguo, pues con la palabra «retrato», el autor ha querido probablemente aludir tanto a la imagen habitual del ciego glosando las estampas sueltas o incluidas en pliegos de cordel que vende, como a la imagen de Santo Domingo que apareció en Soriano.

Una figura cuya existencia en el siglo XVII sólo podemos probar mediante referencias literarias es el «mozo de estampas», que parece ser acompañaba a los ciegos con la misión de guiarles y vender estos objetos. Así al menos actúa en El gran mercado del mundo, un auto de Calderón en el que representa a la Culpa, que trata de guiar a la ciega Gula:

Salen la Gula, de ciego, y la CulPa, de mozo de estampas:

MUNDO.- ¿Quién eres tú, que en vano solicito / conocerte?

GulA.-Yo soy el Apetito / del hombre; ciego voy, porque, aunque enfrente / le tenga, jamás vi el inconveniente.

CulPa.-Y por eso le guío / yo, que de los peligros le desvío.

MUNDO.- ¿Qué es tu caudal?

GulA.-Pinturas, que pintadas / todas mis glorias son imaginadas, / porque tanto apetece / el hombre, el Apetito se lo ofrece, / trayendo a su memoria los empleos / de gustos, de manjares y deseos ${ }^{44}$.

El carácter de la didascalia, de los versos y de la obra en general, en la que participan los principales tipos de vendedores, invita a pensar que el «mozo de estampas» constituía una figura conocida por la amplísima audiencia de los autos sacramentales y era habitual en las calles de las ciudades. Debía de tratarse del lazarillo que solía acompañar a los ciegos y se encargaría de vender las estampas, unos objetos que, por su carácter

43 Varias poesías (Biblioteca Nacional de Madrid, Mss. 17666), 120. Sobre las estampas que adornaban los pliegos de cordel véase Luis CORRALES DE PRADA, «La ilustración en lo0s pliegos sueltos del siglo XVI. Relación entre imagen y texto», Goya, n. 181-182 (1984-1985), 21-22.

44 Pedro Calderón, Obras completas, Ed. Ángel Valbuena (Madrid: Aguilar, 1952), III, 234. 
sustancialmente visual, no podían ser diferenciados por éstos cuando sus tamaños eran similares.

A pesar de que los párrafos anteriores han demostrado que las estampas a veces se contaban entre los objetos que vendían los ciegos, la mayoría de los textos que aluden a sus actividades comerciales, y que han sido en buena parte recogidos por Rodríguez Moñino ${ }^{45}$, sólo se refieren a la venta de pliegos de cordel, de la que poseían en el siglo XVII el monopolio. No sabemos si esto debe interpretarse como que este tipo de literatura era el único objeto de venta de muchos de estos personajes, o si se debe a que, aunque también vendieran estampas, los pliegos de cordel eran su principal artículo, además del elemento que mejor servía al escritor para caracterizarlos y diferenciarlos de los demás vendedores. Por otra parte, la alusión a estos objetos proporcionaba al poeta una oportunidad, muchas veces aprovechada, de reflexionar sobre un género literario de gran importancia social. Del mayor atractivo que encontraba un escritor en un pliego de cordel que en una estampa, y que explicaría la comentada falta de alusiones a la venta de éstas por ciegos, tenemos un ejemplo significativo en la comedia de Lope Juan de Dios y Antón Martín. Allí, aunque el santo portugués aparezca vendiendo «coplas y estampitas», los únicos comentarios se refieren a aquéllas, cuyos temas le sirven al escritor para definir las inclinaciones religiosas del santo y diferenciarlas de las más profanas de los compradores *

Junto a personajes que, como los ciegos o el protagonista de esta última cita, incluían a las estampas entre los variados objetos de su comercio, existían otros que se dedicaban a su venta de forma exclusiva: se trata de los estamperos. En realidad, ésta es una palabra de significación imprecisa, pues designaba tanto a los impresores como a los vendedores ${ }^{47}$; y en sólo dos de las varias alusiones literarias a estos últimos que hemos encontrado se utiliza semejante término. Una de ellas se encuentra en la Vida y muerte del rey Bamba, una comedia que escribió Lope hacia 1597, en la que el personaje que da su nombre a la obra, al ser elegido alcalde de su concejo y percatarse de la carencia de imágenes religiosas en la sala donde reparte justicia, reclama la presencia de un estampero. Lope era probablemente consciente del anacronismo que supone hacer de un godo un consumidor

45 Antonio Rodríguez MoÑIno, Diccionario bibliográfico de pliegos sueltos poéticos (s. XVI) (Madrid: Castalia, 1970), 85-126.

46 Obras de Lope de Vega, Ed. M. Menéndez Pelayo (Madrid: Atlas, 1963-1972), XI, 288-289.

47 «Y así, dice que don Antonio Moreno, a imitación de otra cabeza que vio en Madrid, fabricada por un estampero, hizo ésta en su casa». Miguel de Cervantes, Don Quijote de la Mancha, II, lxii, Ed. Juan Bautista AvAlLE-ARCE (Madrid: Alhambra, 1979), II, 529. A este pasaje remite el Diccionario de Autoridades en su voz «Estampero». 
de estampas. Pero ha elegido precisamente estos objetos, los más humildes de cuantos tienen una función figurativa, para definir no sólo el tipo y la intensidad de la religiosidad del futuro rey, sino también la humildad del entorno que le rodeaba y su voluntad de alejarse de tentaciones suntuarias, que mantendrá hasta el final de la comedia. En este sentido, las estampas juegan un papel similar al que desempeña la imagen de San Roque en Peribáñez:

BAMBA.-Un hombre que está vendiendo / estampas me traed acá.

BERRUECO.-Al momento se traerá.

BAMBA.-Esto, amigo, os encomiendo; / tengo de una cosa espanto, / que poco me satisface: / que donde justicia se hace, / no es razón que esté sin santo.

(Entra el estampero con estampas.)

ESTAMPERO.- ¿Qué es lo que mandas, señor?

BAMBA.-Aquí una estampa querría.

ESTAMPERO.-_Es de la Virgen María, / o su Hijo el Salvador? / Declárame el modo o cómo: / ¿Es en la cruz por ventura, / en la calle de Amargura, / azotado o Eccehomo?

BERRUECO.-¿¿Decid, Bamba, qué lloráis?

BAmBA.-Soy tierno de corazón, / y en mentando la Pasión, / lloro así; ¿qué os espantáis? / Esto es razón que se note: / por acá se suena, hermano, / que al obispo toledano / la Virgen le dio un capote.

ESTAMPERO.- ¿Es la casulla que dio / a Ildefonso soberano / María, y su santa mano?

BAMBA.-Sí, sí, esa quiero yo.

ESTAMPERO.-Veisla aquí.

BAMBA.-Santo cielo! / Que con vestido tan bueno, / no os haría daño el sereno, / ni os podrá ofender el hielo. / Encima de esta pared / del Audiencia la pondremos, / y todos le rogaremos, / y a todos hará merced ${ }^{48}$.

En esta cita vemos que, para caracterizar ideológicamente a un personaje, tiene tanta importancia la opción por un determinado medio artístico como la iconografía que a través de él se vierte.

Otro estampero de cierta importancia argumental es el que aparece en el auto El yugo de Cristo, en el que pudo intervenir Lope de Vega. Allí encarna a la Idolatría, que trata de vender estampas que representan la Riqueza, la Hermosura, la Venganza, el Juego, la Avaricia, la Codicia y la Gula, al Hombre, quien se debate entre los consejos contrapuestos que las personificaciones de la Razón y el Apetito le brindan:

48 Obras de Lope de Vega, Ed. M. Menéndez Pelayo (Madrid: Atlas, 1963-1972), XVI, 308-309. 
Sale la IDOLATRfa con unas estampas.

IDOLATRIA.- ¿Quién compra estampas bellas / de los divinos dioses celestiales, / para adorar en ellas? / ¿Quién compra las deidades inmortales? / ¿Quién, por mayor decoro, grandes de mármol y pequeñas de oro? / ¿Quién compra las figuras / de Fidias, de Lisipo y Praxiteles, / pinturas, esculturas? / ¿Quién compra cuadros del divino Apeles?

HOMBRE.- ¡A qué buen tiempo llega!

APETITO.-Con las estampas de los dioses ruega.

HOMBRE. - Mostrad, hermosa dama, / esas estampas.

IDOLATRfa.-Todas son muy finas; / de pintores de fama, / estas son las deidades más divinas ${ }^{49}$.

En el resto de la escena le va mostrando estampas con las personificaciones citadas, algunas de las cuales (Avaricia, Venganza y Gula) coinciden en ciertas características con la descripción que hace de ellas Ripa en su Iconología. Como en la cita anterior y en muchas otras piezas dramáticas de Lope, se advierte en ésta un deseo de conceder un papel caracterizador de ambientes y personajes a los distintos medios artísticos o a la calidad de las obras de arte. Así, por ejemplo, la humildad de San Isidro se expresa, entre otras cosas, mediante la modesta sarga que cubre sus paredes; el uso de vajilla talaverana denota humildad económica o de carácter; una estampa, lo hemos visto, sirve para definir el cuarto de un criado; y el arrogante y poderoso protagonista de La quinta de Florencia engalana su casa con pinturas de Tiziano y Miguel Ángel, cuya contemplación le provoca una pasión violenta. En este caso, la Idolatría trata de atraerse al Hombre no sólo a través del significado de sus estampas, sino también por medio de la calidad y belleza de éstas, invocando nombres como los de Fidias, Lisipo, Praxiteles o Apeles. Este cierto prejuicio moral contra el poder seductor del arte define buena parte de la práctica y la teoría del arte de la España contrarreformista, y se encuentra en ocasiones referido en Lope tanto a la inconografía como al valor de los materiales o, incluso, a la calidad de ejecución.

Una escena similar a la que aparece en El yugo de Cristo la encontramos en el auto de Lope La margarita preciosa, aunque en este caso las estampas no se ofrecen sueltas, sino que forman parte de un libro que vende un mercader que personifica al Demonio:

Salen el Demonio, vestido de mercader, con un libro, y los Músicos.

DEMONIO.- ¿Hay quién compre, caballeros, / aqueste libro encantado, / que tantos por él me han dado / tantos ruegos y dinero? / ¿Hay quién le quiera comprar? (...)

\footnotetext{
49 Ibid., VII, 67-68.
} 
MERCADER.- ¿Qué lindas figuras son / de campos y de riquezas! / ¿Vivas dais estas bellezas? ${ }^{50}$.

La frecuente presencia de alusiones a obras de arte en el teatro clásico español en muchos de los casos se explica porque éstas son portadoras de una iconografía que se constituye en reflejo de la trama argumental de la pieza dramática. El tema no ha pasado desapercibido a los filólogos; pero sí a los historiadores del arte, a pesar de las posibilidades que ofrece para estudiar la manera cómo percibía e interpretaba el público las obras artísticas. Una de las imágenes que más frecuentemente se repiten en este tipo de alusiones es la de Venus y Adonis, que es precisamente el tema que está representado en una estampa que muestra Valerio, disfrazado de estampero, a su amada Leonarda. Ocurre en La viuda valenciana, una comedia de Lope de Vega repleta de alusiones autobiográficas:

VALERIO, en hábito de mercader, con estampas.

VALERIO.- ¡A la rica estampa fina!

(...)

LEONARDA.-Mostrá, ¿qué es este papel?

VALERIO.-El Adonis del Tiziano, / que tuvo divina mano / y peregrino pincel.

/ ¡Oh quién éste hubiera sido, / cuando fue tan regalado! / Pues muero desesperado, / y él murió favorecido. / Esta, por vida de Aurelio, / que es de las ricas y finas; / que es de Rafael de Urbinas / y cortada de Cornelio. / Esta es de Martín de Vos, / y aquesta de Federico.

LeONARDA. - Mal a estas cosas me aplico. / ¿No traéais cosas de Dios? ${ }^{51}$.

Más adelante Lisandro utiliza la palabra «estampero» para aludir a Valerio. F. A. de Armas ha visto en la mención al Venus y Adonis de Tiziano un deseo de Lope de Vega de reflejar la peculiar relación que se establece entre Leonarda y Camilo, los dos protagonistas de la obra: ella le "persigue» a él, algo poco frecuente en la producción del escritor. Esto supondría un conocimiento preciso del significado del cuadro del veneciano, quien, según Panofsky ${ }^{52}$, dio la vuelta al mito antiguo y en realidad representó a Venus tratando de evitar que Adonis «huyera» de su vera ${ }^{53}$. Es posible, aunque no está claro, que la tesis de Armas sea cierta y que Lope fuera consciente de la significación del cuadro del veneciano; pero la mayor parte del público

\footnotetext{
so lbid., VII, 163-164.

51 Comedias escogidas de Lope de Vega (Madrid: Atlas, 1946-1952), I, 74.

52 Erwin Panofsky, Problems in Titian (Nueva York: 1969), 152.

53 Frederik A. ARMAS, «Lope de Vega and Titian», Comparative Literature, XXX
} (1978), 338-352, y «Italian Canvases in Lope de Vega's Comedias: the case of Venus and Adonis», Crítica Hispánica, II (1980), 135-143. 
que asistía a los corrales nunca había visto la pintura y no conocía la transformación que en ella se había operado respecto del relato clásico; un mito que, a juzgar por lo extendido que estuvo en todas las formas de literatura, podemos considerar casi del dominio público. Esto lleva a plantearnos la existencia de dos niveles distintos de significación en la alusión de la comedia. El primero, más sutil, lo acabamos de ver, y sólo sería accesible a unos pocos iniciados; y en cuanto al segundo, lo explica Valerio en sus versos.

Este pasaje, bastante conocido, ofrece otros motivos de reflexión. Tiene cierto interés la relativa condena moral, un tanto hipócrita, que hace Leonarda a estas estampas debido a su iconografía. Es también expresivo de un fenómeno que, por desgracia, caracterizó la difusión del grabado en la España barroca: nos referimos a la procedencia extranjera de la casi totalidad de las estampas sueltas de tema profano y de calidad. Por otra parte, nos indica que éstas eran consumidas, entre otros, por personas de las clases más o menos acomodadas, a las que pertenecía Leonarda, quienes frecuentemente demandaban obras que reprodujeran pinturas de artistas famosos, en este caso Tiziano, Rafael, Martín de Vos y Federico Zúccaro ${ }^{54}$.

En contraste con la relativa abundancia de referencias literarias al consumo de estampas, apenas hay alusiones a sus autores, los grabadores. Una de las pocas que existen aparece en El Criticón, en cuya crisis XII de la tercera parte, dedicada a la isla de la Inmortalidad, se habla de un soldado fanfarrón que a costa de amenazas y bravuconerías había logrado un puesto entre los inmortales, aunque a regañadientes de otros militares y de los escritores que se habían visto obligados a alabarle. Incluso «hasta un abridor de planchas se excusó de haber metido su retrato entre los hombres insignes, diciendo que para hacer número y tener más ganancia. Con lo cual quedó el tal jefe confundido, aunque no del todo desengañado" ". Los libros de retratos de hombres famosos circularon bastante por España, aunque su procedencia era siempre extranjera y en nuestro país el único intento serio de elaborar uno, el de Pacheco, sólo pasó muy parcialmente a la imprenta ${ }^{56}$. Su proliferación encuentra un paralelo en la presencia de series de este tipo de retratos en casi todas las colecciones pictóricas privadas

54 A identificar a «Federico» con Zúccaro invita lo apreciadas que fueron sus estampas en la península, un fenómeno del que se hizo eco Palomino en su Parnaso... (Ed. Nina Ayala, Madrid: Alianza, 1986, 73). En cuanto a «Cornelio», se trata de Cornelio Cort, el importante grabador flamenco establecido en Italia en torno a 1571.

55 Ed. Evaristo CoRrea (Madrid: Aguilar, 1971), II, 316.

56 Unos pocos dibujos fueron grabados por Alardo de Popma y Francisco Heylan. Véase J. Carrete, «El Libro de Retratos de Pacheco», Goya, n. 193-195 (1986-1987), 168-173. 
españolas ${ }^{57}$, y se relaciona con la intensificación del culto a la personalidad que se produjo en la Edad Moderna.

Un grabador es el protagonista de una anécdota que incluyó Francisco Asensio en su Segunda parte de la floresta española. Aunque desborda ligeramente los límites cronológicos de este artículo, creemos que no está de más reproducirla:

Abrió un artífice la lámina de un gran héroe, que había muerto; y como lo supiesen sus gentes, se opusieron ocurriendo al juez, para que mandase recoger la lámina y quemar las estampas que se habían sacado, alegando por pretexto, que no se parecía al original. El juez condescendió a su petición, mandando se executase así. Agraviado el artífice de este procedimiento acudió al rey, apelando del agravio. El Rey mandó que se le volvieran y en el memorial decretó: "Que Su Majestad siendo Rey permitía que sus retratos en nada parecidos y bien mal hechos se vendiesen por las esquinas, por el corto lucro que podían tener sus vasallos, a fin de que estos se fueran adelantando en las ciencias y artes, que era lo que deseaba ${ }^{58}$.

En realidad, Asensio no ha hecho más que adaptar una anécdota muy conocida que tiene como protagonistas a Felipe II y a un pintor, y que circulaba por España desde hacía más de un siglo. Se refiere a la condescendencia del constructor de El Escorial para con los malos pintores que realizaban retratos suyos de mala calidad; pues aunque no atinaran a reproducir fielmente su físico, al menos no intentaban representar sus costumbres ${ }^{59}$. En todo caso, ésta es una más de entre las muchas alusiones que la Edad Moderna nos ha dejado sobre el tema del decoro, entendido éste como una adecuación entre significante y significado.

Al igual que hizo con la mayor parte de los objetos naturales o artificiales conocidos, la literatura de los Siglos de Oro utilizó la estampa en ocasiones como término de comparación. Aquí sólo vamos a referirnos a dos alusiones de cierto interés. El prolífico y un tanto mediocre Alonso de Bonilla construye un soneto comparando la estigmatización de San Francisco de Asís con los procesos de grabado e impresión. Entre las razones que dan interés a la pieza debemos contar su relativa riqueza terminológica:

57 José Miguel MORÁn y Fernando CHECA, El coleccionismo en España (Madrid: Cátedra, 1985). Incluyen numerosos ejemplos.

58 Data de 1730. Citamos por Francisco Javier SÁnChez Cantón, Fuentes literarias para la historia del arte español (Madrid: C.E.H., 1926-1941), V, 514.

59 María Cruz Garcfa de EnTERrfa, «Un memorial casi desconocido de Lope de Vega», Boletín de la Real Academia Española, LI (1971), 139-160, o Miguel HeRrero GARCIA, «Un dictamen pericial de Velázquez y una escena de Lope», Arte Español, XIII (1936), 66-68. 


\section{DE SAN FRANCISCO}

Queriendo abrir alguna imagen bella en la dispuesta plancha lisa y dura, fuerte buril el tallador procura, para romper la gran dureza della.

Mas ya passado el curso de rompella, y transformada en arte la lisura con más facilidad su hermosura en el blando papel se imprime, y sella;

Clavos, y lança fueron los buriles que en la plancha fiel de Christo abrieron las armas con que el hombre se levanta.

Pero después, sus ásperos perfiles, Francisco, a menos costa se imprimieron en el papel de vuestra carne santa ${ }^{60}$.

Probablemente no es ninguna casualidad que, como demostró López Sanabria, el autor de este poema, el único que conocemos del Siglo de Oro dedicado al grabado, fuera también platero ${ }^{61}$. Desde sus orígenes, el arte del grabado estuvo muy vinculado a la platería, debido sobre todo a afinidades técnicas y de materiales, y en la época en la que escribía Bonilla no faltaban plateros españoles que también manejaban el buril de grabador, como Pedro Ángel, Juan Bautista Vilar ${ }^{62}$ o Alberto Fernández, a quien se considera introductor del grabado calcográfico en Granada ${ }^{63}$.

Otra alusión literaria a estampas se encuentra en las Noches claras del poeta portugués Manuel de Faria, quien parece ser que tenía cierta habilidad para el dibujo. Tiene interés desde el punto de vista de la historia de la estética por sus reflexiones sobre la luz y el color:

SANAZARO.-La belleza es correspondencia de partes, y armonía de colores.

ElASO.- Yo digo, que he visto muger, en cuyo rostro no parecía más de un pálido candor, o palor (sic) cándido; y no por esso, falto de colores, dexava de ser hermoso.

Lus.-Esso es, que como las partes (aunq sin colores) se corresponden perfectas, y llevan aquel divino espíritu que las ilumina y mueve, agradan la vista, como la nieve herida del Sol, que con sólo su candor resplandece hermosamente en quanto le toca el rayo: o como se vería en una estampa que el diestro ilumi-

60 Peregrinos pensamientos (Baeza: Pedro de la Cuesta, 1614), fol. 165r.

${ }^{61}$ "Alonso de Bonilla. 129 poesías autógrafas e inéditas", Boletin del Instituto de Estudios Giennenses, X (1964), 28.

62 B. GARCiA VEGA, El grabado del libro español, Op. cit., II, 267.

63 Antonio Moreno GARrido, «El grabado en Granada durante el siglo Xvil. La calcografía», Cuadernos de Arte de la Universidad de Granada, XIV (1976), 52-53. 
nador, ausentes las colores, cuydadoso con el oro preparado, retocasse solamente, donde la luz sin colores viene a servir de gracia particular, lo que no sucediera si ella faltasse, como se ve en el farol con lumbre, o sin ella ${ }^{64}$.

Aunque las más significativas, no son éstas las únicas alusiones que encontramos en la literatura de los Siglos de Oro a las estampas, unos objetos que, debido a su bajo coste, poseerían la mayoría de nuestros antepasados, quienes las utilizaban, como hemos visto, con fines preferentemente devocionales y las adquirían en las calles a los estamperos. Era éste un tipo de vendedor al que en páginas anteriores se ha tratado de definir acudiendo a las obras literarias, las cuales se revelan como magníficos complementos de otras fuentes históricas, a las que aportan una voluntad valorativa.

JAVIER PORTÚS PÉREZ

A través de las fuentes literarias se ha tratado de realizar un estudio valorativo de la función de la estampa suelta en la sociedad española del Siglo de Oro, y de arrojar cierta luz sobre los estamperos, un tipo de vendedor del que, aunque se conocía su existencia en la España barroca, se ignoraban muchas de sus características. Por último, se ha observado cómo frecuentemente las estampas han sido utilizadas por los escritores para definir y caracterizar ambientes y personajes, y para reflejar en algún caso una trama argumental.

By means of literary sources, this paper tries to make an appraisal of the meaning of the prints in the Spanish Golden Age society, as well as to throw some light over the «estampero» (print seller), a sort of seller about whom little was known, although his presence in Spain is documented. Finally, the point is made that the writers did use very often the prints, both to define and to portray milieus and characters and sometimes even to mirror a plot.

LÁM. I. San Francisco confortado por un ángel. Atribuido a Ribalta. Hartford, Wadsworth Atheneum.

LÁm. II. San Jerónimo penitente. A. de Pereda. Madrid, Museo del Prado.

LÁM. III. «El de la Rollona». F. de Goya, Capricho n." 4.

LÁM. IV. «Mujer sentada». Atribuido a A. Puga. Madrid, Museo del Prado.

64 (Madrid: Viuda de Cosme Delgado, 1624), 454. 


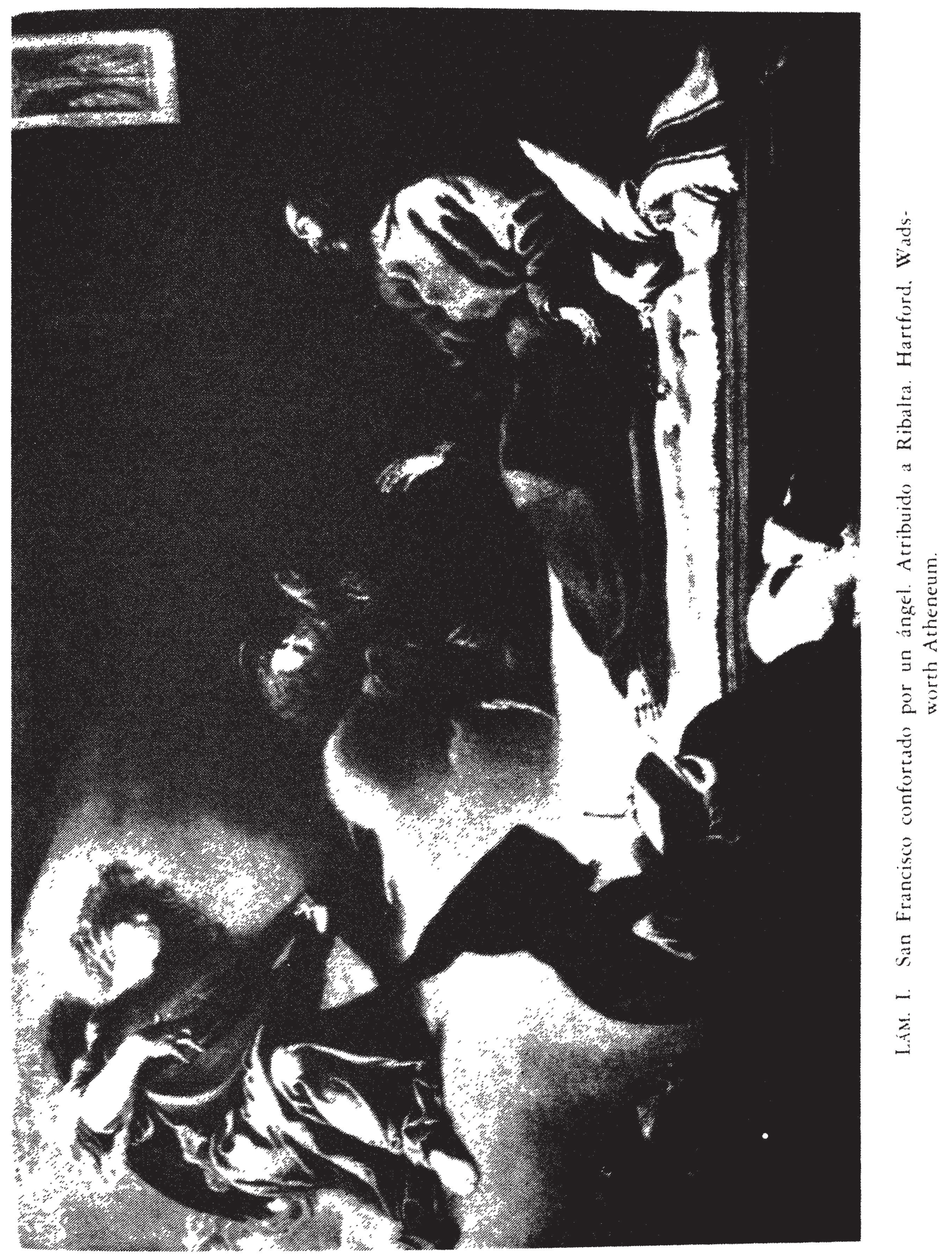

(c) Consejo Superior de Investigaciones Científicas 


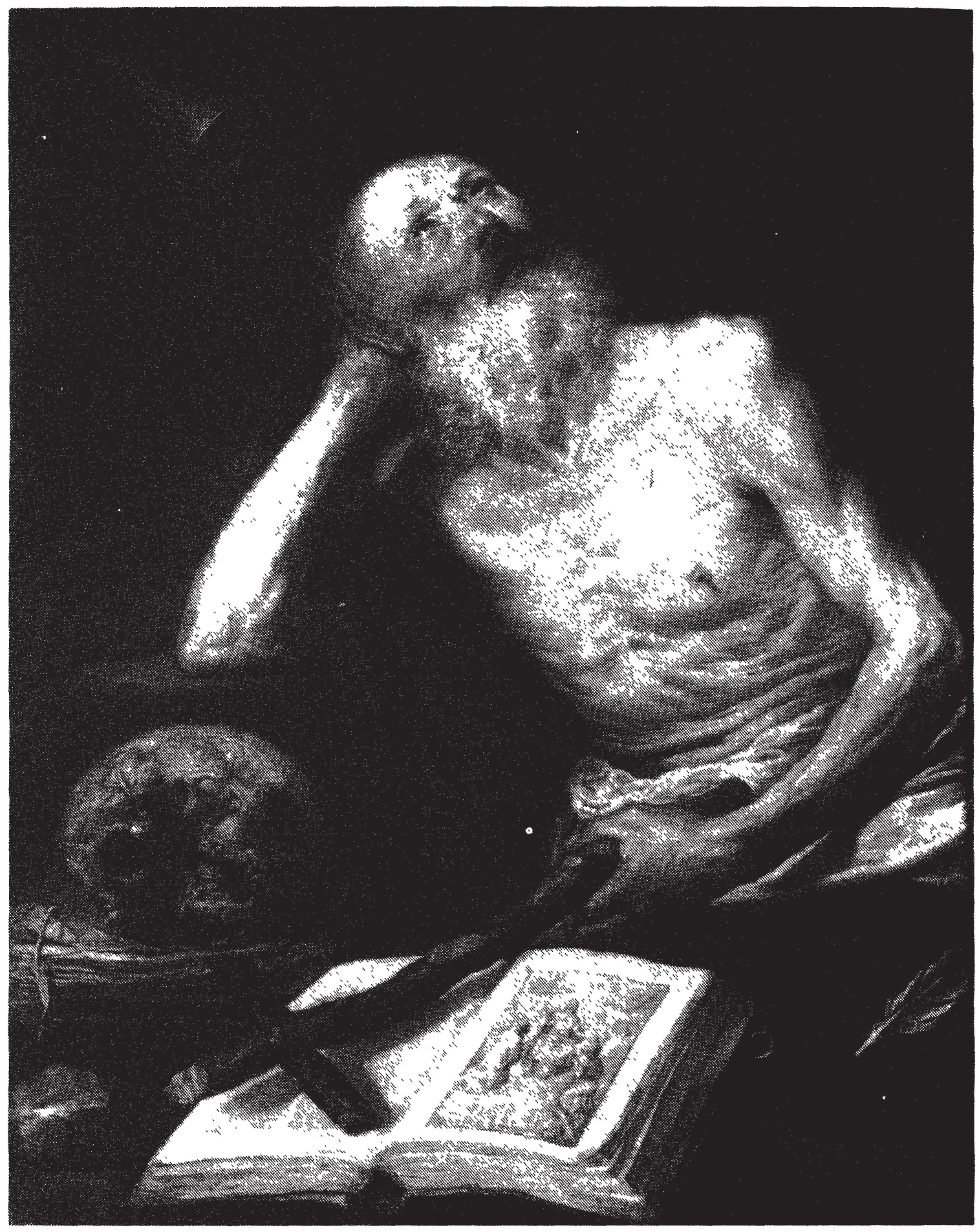

Lam II. San Jerónimo penitente. A. de Pereda. Madrid, Museo del Prado. 


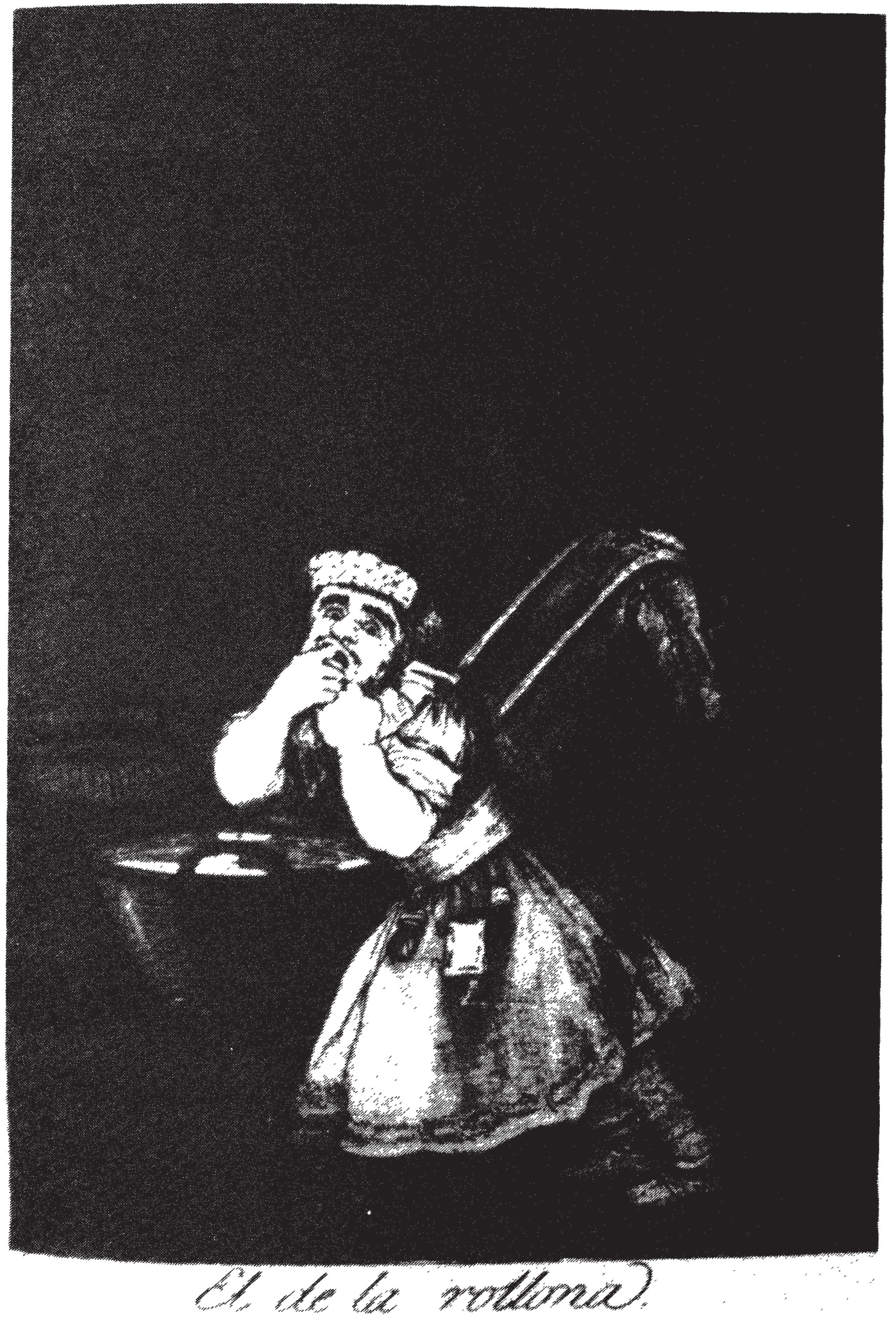

LÁm. III. "El de la Rollona» F. de (onya, Capmuln n. i.

(c) Consejo Superior de Investigaciones Científicas 


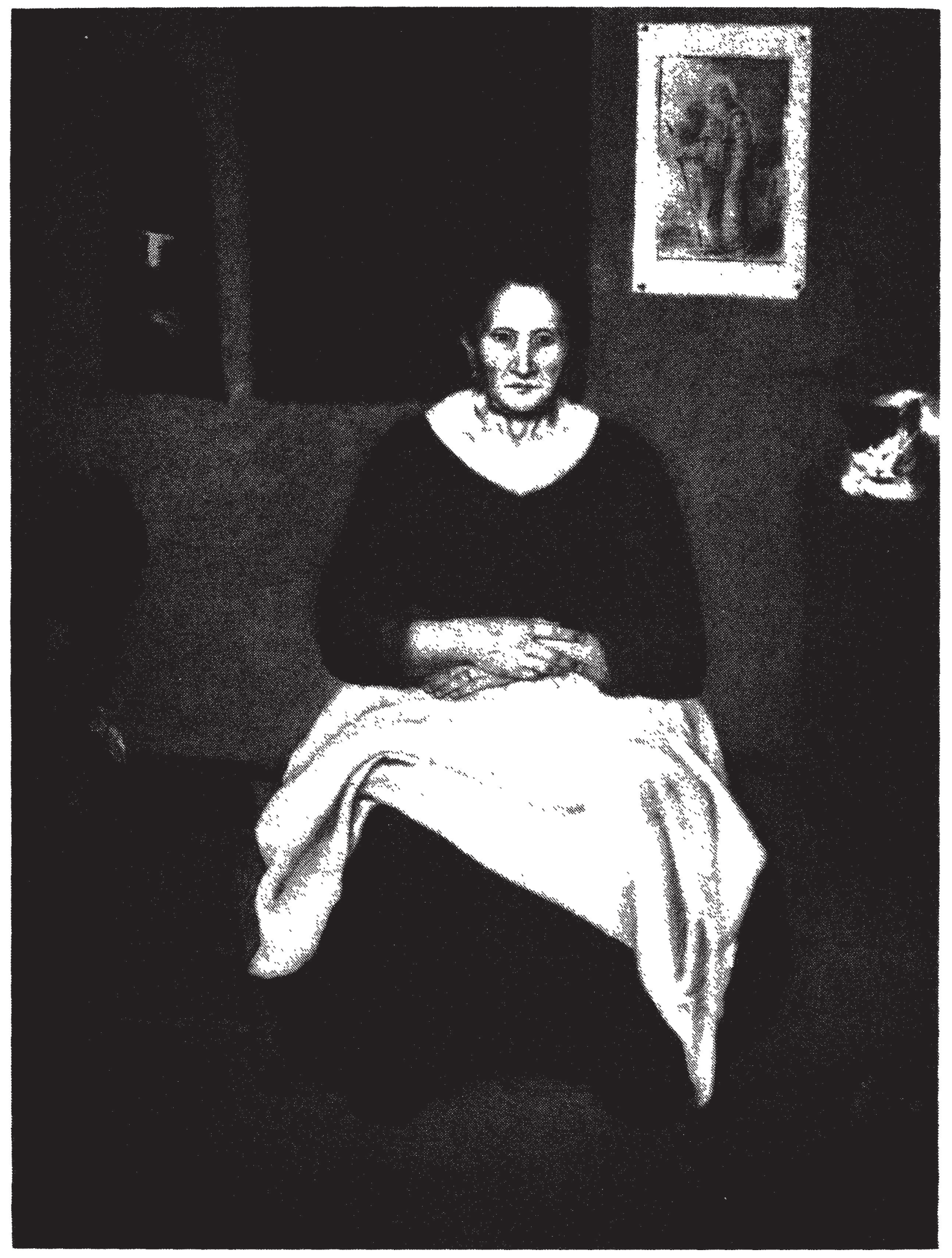

LÁm. IV. «Mujer sentada». Atribuido a A. Puga. Madrid, Museo del Prado.

(c) Consejo Superior de Investigaciones Científicas 


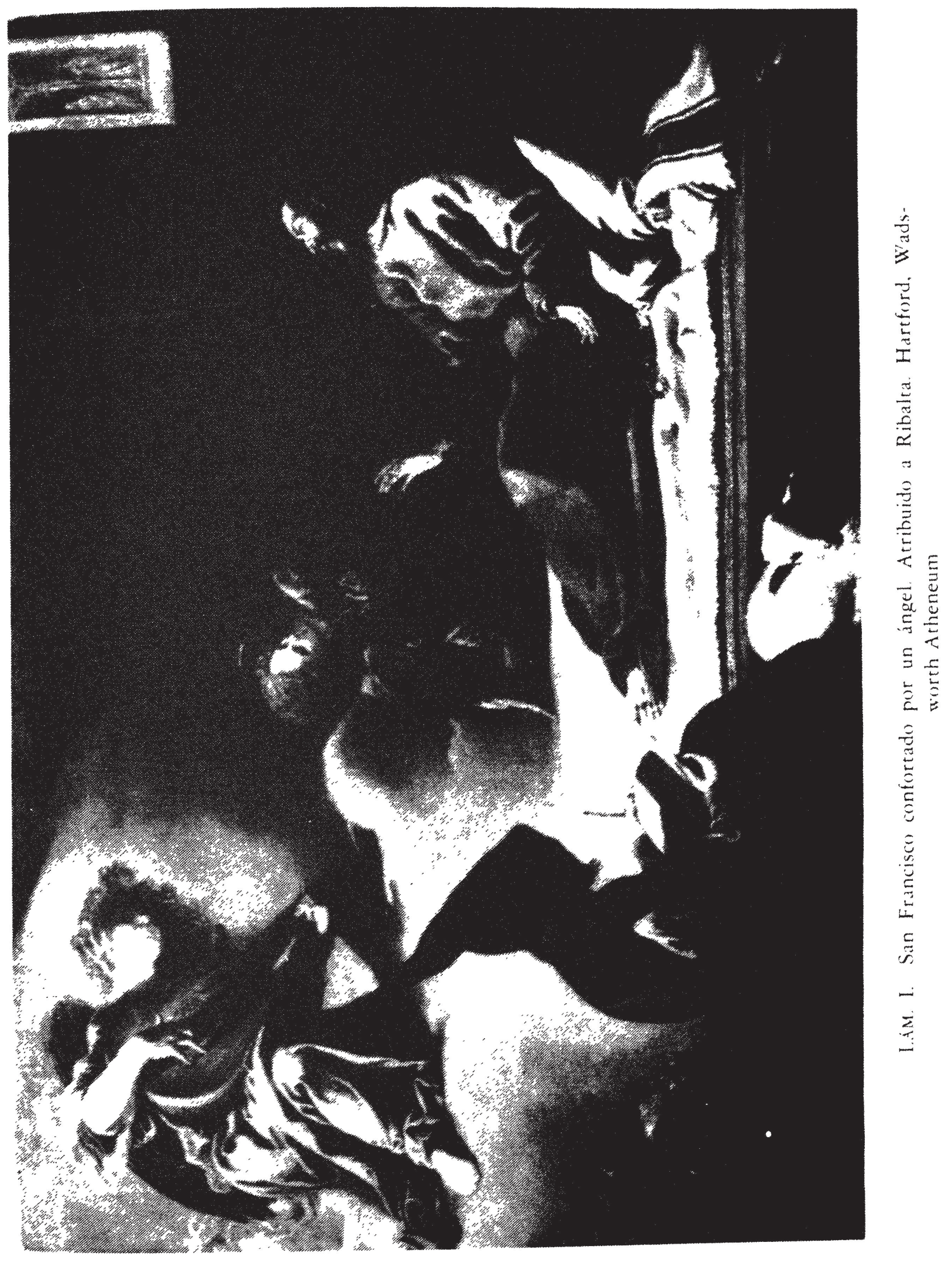

(c) Consejo Superior de Investigaciones Científicas 


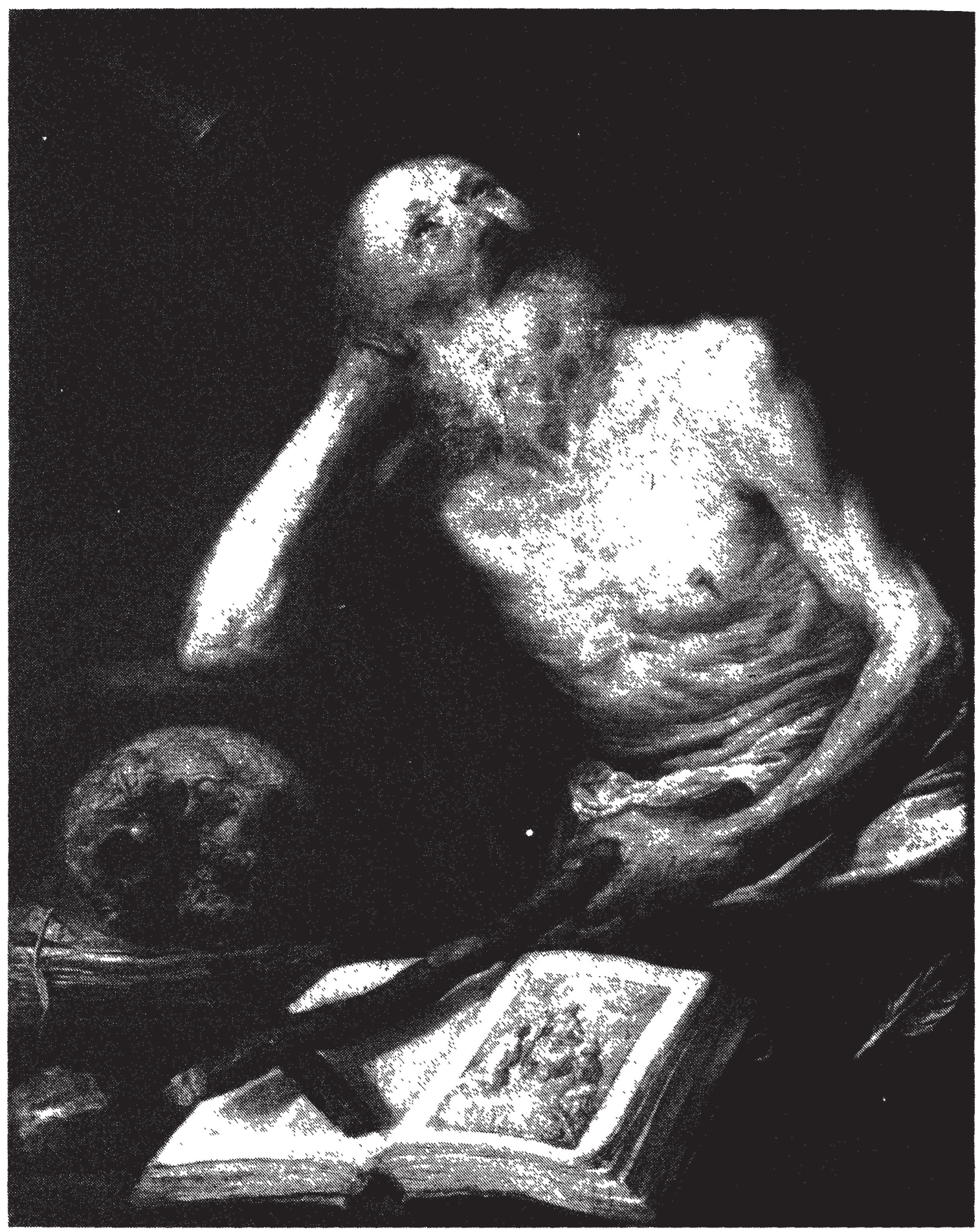

LAM. Il. San Jerónimo penitente. A. de Pereda. Madrid, Museo del Prado. 


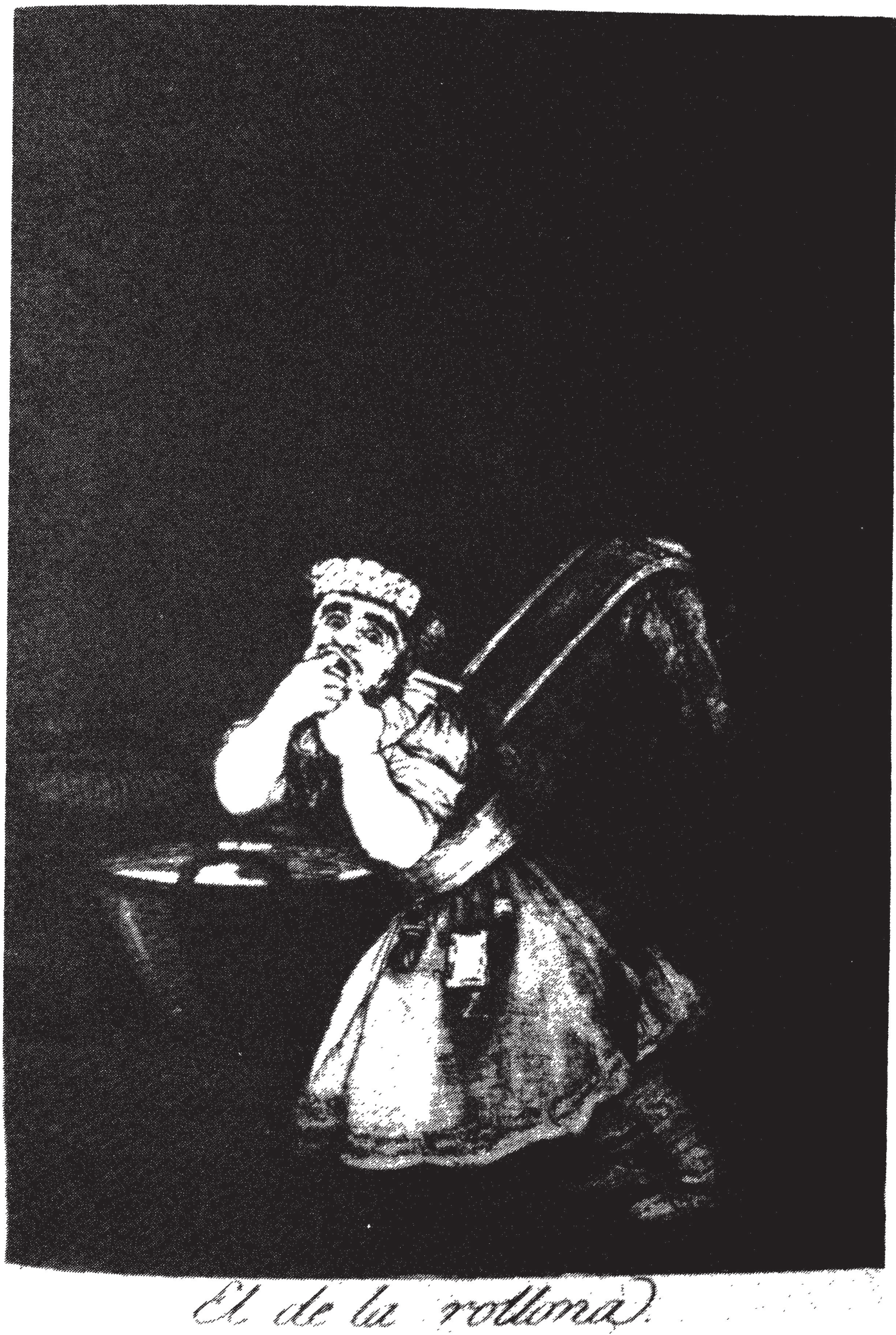

LÁM. III. "El de la Rollona" F de (ioyáa Capriblenn i.

(c) Consejo Superior de Investigaciones Científicas 


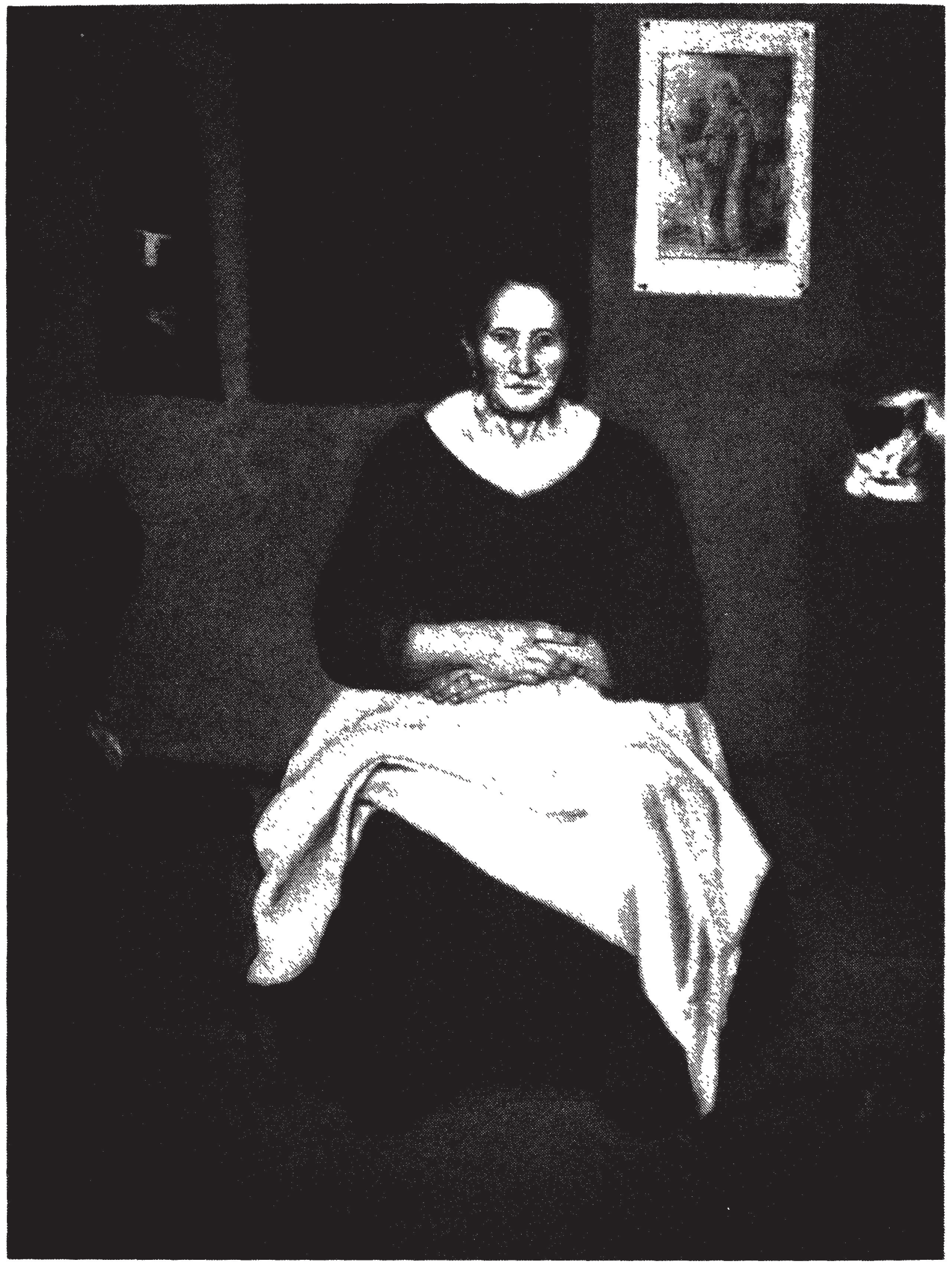

LÁM. IV. «Mujer sentada». Atribuido a A. Puga. Madrid, Museo del Prado.

(c) Consejo Superior de Investigaciones Científicas 